\title{
La enseñanza y el aprendizaje de la Historia en México. Datos de su trayectoria
}

en la educación secundaria

por Laura H. Lima Muñiz y Rebeca Reynoso Angulo

Universidad Pedagógica Nacional / Instituto Nacional para la Evaluación de la Educación, México laurali09@yahoo.com.mx, reynosor_@hotmail.com.

Recibido: 21/04/2014 . Aceptado: 13/05/2014

\section{Resumen}

La enseñanza de la Historia en la educación primaria y secundaria en México igual que en otros países, se caracterizó hasta hace apenas unos lustros, como una asignatura escolar cuyo objetivo era la transmisión de datos, la repetición de nombres de los personajes más destacados, la memorización de fechas, lugares y batallas. Con ello se propiciaba principalmente un aprendizaje memorístico distante del desarrollo de habilidades metacognitivas en los estudiantes. Actualmente cobra importancia el hecho de que los nińos y adolescentes aprendan a pensar históricamente. Esta concepción originó un cambio sustancial en la percepción de los maestros de educación básica sobre lo que representaba enseñar Historia, y lo que implica su aprendizaje en la educación secundaria. En este texto damos cuenta de los cambios en la visión de la enseńanza de la Historia como parte de la formación integral de los estudiantes de educación básica en México.

Palabras clave

enseñanza de la Historia, competencias, currículo, reforma educativa

$\cos$

\section{Teaching and learning history in Mexico. Details of the career in secondary school}

\section{Abstract}

History on primary and secondary schools in Mexico, as in many other countries, had until recently been characterized as a subject dedicated to the transmission of information and memorization of the most important names and characters, dates, places and battles. This meant that priority was given to memorizing instead of developing metacognitive skills amongst students. In the last few years it has been broadly accepted that it is important that students learn to think historically. Th 
perception about what it means to teach history, and what it's learning implies in secondary schools. This text elaborates on the changes in the perspective of teaching history as a part of the integral formation of basic education students in Mexico.

Keywords:

History Teaching, curriculum, competencies, educational reform.

\section{Antecedentes}

cos

La educación obligatoria en México ha sufrido cambios importantes a lo largo de su vida independiente; durante las primeras décadas de la vida de nuestro país sólo se ofrecía la educación elemental o primaria como tramo obligatorio de escolaridad. Ahora a casi $200 \mathrm{de}$ consumada la independencia, la educación obligatoria es de 15 años y se organiza de acuerdo con el siguiente esquema:

Educación obligatoria

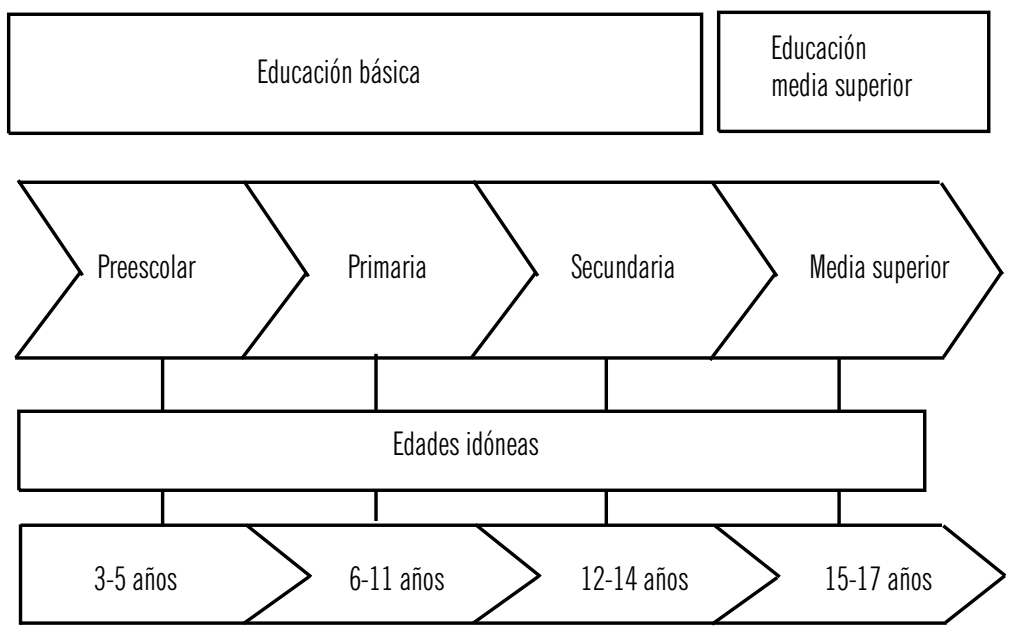

Con el propósito de contribuir a la refl

ámbito de la enseñanza de la Historia en la educación pública en México, se presenta un breve contexto, identifi

en el currículo de educación básica a partir del nacimiento de México en su vida republicana, cuando liberales mexicanos como José María Luis Mora proclamaban que el elemento más importante para la prosperidad de un pueblo «es un buen uso y ejercicio de su razón» lo que sólo se lograría a través de la educación. 